\title{
The Legitimisation of Soccer in Australia: A Theoretical Analysis
}

\author{
Andrew Harper ${ }^{1, *}$ \\ ${ }^{1}$ Faculty of Arts and Social Work, The University of Sydney, NSW, Australia \\ *Correspondence: Faculty of Arts and Social Work, The University of Sydney, NSW 2006, Australia. E-mail: \\ ahar3444@uni.sydney.edu.au
}

Received: February 11, 2019 Accepted: March 13, 2019 Online Published: April 3, 2019

doi:10.5430/wjss.v6n2p1 URL: https://doi.org/10.5430/wjss.v6n2p1

\begin{abstract}
Weber's legitimacy theory has been diffused widely throughout the corporate and political context but not to the sporting world. This paper adopts Weber's legitimacy theory to better understand the context of Australian sport, particularly as it relates to soccer's standing in the culture. For the majority of its Australian existence, soccer was not part of the mainstream, and academic and other writing has labelled it illegitimate. However, despite appropriating the illegitimacy label, no theoretical model has been applied to the assertion. Weber's Theory of Legitimacy depicts three types of legitimacy; charismatic, legal/rational and traditional. This qualitative research utilized interview data collected from a purposive sample $(\mathrm{N}=22)$ of the influential people who determined soccer's legitimacy as a result of the sport's restructure in 2003, through to the nationally acclaimed triumph of winning the men's Asian Cup in 2015. The data was then compared against Weber's theory to better understand soccer's transformation, showing that Australian soccer was legitimised by the recruitment and leadership of Frank Lowy (charismatic), the intervention of the Federal Government (legal/rational) and the inter-generational growth of the sport's popularity and participant base (traditional). This paper not only attempts to theorise Australian soccer but also raises some important questions regarding Australian soccer studies in general.
\end{abstract}

Keywords: legitimacy, weber, Australian soccer, ethnicity, government

\section{Introduction}

Soccer in Australia presented a conundrum. The country's colonial history and institutional Anglophilia should predispose it sympathetically to Britain's most significant, important and popular sport, soccer. However, in Australia, soccer's history is one of marginalisation. The answer to the question as to how such an anglophile country and former colony can have ostracised soccer so consummately has been raised but never satisfactorily answered. Thus far, the vast bulk of academic inquiry has labelled the sport's ethnicity as its delineating death-sentence. Yet, given the almost complete homogeneity of Australian society for the first 160-odd years since British colonization in 1788, this is surely a tenuous claim; that is, how can soccer have been marginalised because of the ethnic makeup of its protagonists whilst, say, rugby union and cricket were not, when all were products of the same cultural gene pool? Undeniably, the post-1950 influx of non-British/Irish immigrants brought a newer soccer cohort to Australia. It also simultaneously fuelled the ethnicity focus. Perhaps this infatuation with multi-ethnic immigrants and soccer led the scholarship to draw-the-longer-bow to include ethnicity as the key variable in colonial times also.

Whichever is the case and as a result, soccer's scholarship has been limited to descriptions of the ethnicity theme and its story has, apparently, been one inextricably infected by 'ethnics', whether Caledonian or Croatian. This has occurred almost at the exclusion of other thematic considerations and, crucially with respect to this paper, has developed without being theoretically informed.

One historian, however, Ian Syson, has more recently and explicitly labelled soccer's struggle as being one of legitimacy. Legitimacy has been raised and appropriated elsewhere, but never tested theoretically. This paper, therefore, sets about addressing the scholarship's underutilisation of theoretical investigation, using legitimacy theory as propounded by German sociologist, Max Weber, to analyse this key consideration.

The $21^{\text {st }}$ century began for soccer with a renewed attitude to the game and its opportunities. Prompted by the soccer 
community, the Federal Government led the sport's restructure, an intervention transmogrifying soccer into unprecedented acceptance as a mainstream, legitimate Australian sport. This epoch for the game has been critical, and with it a critical opportunity to apply Weber's theoretical framework to the body of knowledge.

\section{The Australian Soccer Scholarship Echo Chamber - A Critique of the Literature}

For most of its Australian history, it has been universally agreed that soccer was a marginalised sport. Despite spikes in interest and media coverage at various times (Mosely, 1987; Syson, 2018b), it had never been reported as a mainstream consideration. However, since 2003 and the intervention of the Federal Government, it became common for soccer to be referred to and generally considered as a mainstream sport.

Australian soccer has received increasing attention from scholars since 1979. The major impetus for the initial wave of interest was the multicultural make up of Australian society - a function of post-World War Two immigration policies - and the centrality of the relationship between migrant communities and soccer. Through the 1970's and into the 1980s, multiculturalism came to be "unambiguously at the heart of Australia's developing nationhood and national identity" (Galligan \& Roberts, 2003, p. 7). Harrison (1979) oxygenated the ethnicity theme by publishing "What's in an ethnic name? Soccer clubs in Australia." In 1994 the Australian Society for Sports History released an edited series entitled "Ethnicity and Soccer in Australia". A first and exciting period of soccer scholarship commenced. In surmising that most academic research has reported soccer's position as being a function of its ethnicity and foreignness, Hay $(2006,2011)$ reflected the durability and longevity of the ethnicity focus.

However, the study of soccer has not sufficiently diversified, therefore failing to satisfactorily explain soccer's position in Australian culture. To emphasize the point, Vamplew (1994) wrote about the ethnic contribution to Australian soccer violence, and Vamplew (2017) added another tome to the ethnicity and violence themes regarding Australian soccer; the years have changed but the discussion has remained unerringly loyal. Although they are by no means ploughing a lone furrow, these two papers book-end the period and are an indication as to how little the research dial has been moved. Up until and including most recently (2017-2018) the bulk of research material continues to pivot around issues of immigrant ethnicity, including Kampmark (2017), Gorman (2017), Butta (2018), Knijnik (2018a), Knijnik (2018b), Spaaij and Broerse (2018), and James and Walsh (2018).

Throughout this period, the ethnicity material has typically taken one of two thematic paths. In writing about the relationship between soccer and the Muslim minorities in Australia, Al Ganideh (2018) continues coverage of a first identifiable stream; the role of soccer in assuaging the migratory experience of "new" Australians. In revisiting issues around Balkan ethnicities and politics in Australian soccer - a topic covered by Mosely (1994) - Kampmark (2018) is an example of the second clearly identifiable stream of soccer's scholarship, that ethnicity was problematic for the game in Australia. The multiplicity of issues experienced by soccer have moved far and wide from Mosely's time, but the research boomerang continues to faithfully return. The rehashed coverage linking Balkan ethnicity with soccer violence in Australia (Kampmark, 2018) shows the doggedness with which analysis has held to the ethnicity dichotomy and which shows little sign of abatement. Moreover, this body of knowledge has remained largely historical, descriptive and atheoretical in nature.

A rare exception to this was Hughson (2000) who reflected upon group masculinity theory to explain fan subculture of a Croatian community club in Sydney. Another is Carniel (2009), which adopted gender and post-modern theory to explain the rise of soccer through the A-League. Even these, though, assumed the causal link of ethnicity. Nevertheless, the work draws on theory to provide an explanation for an important part of soccer's arrival to what is reported as soccer's newly-minted "mainstream" status (Carniel, 2009).

Since those early pioneering research days, soccer's Australian canvass has offered a range of theory-driven investigative opportunities. For example, the title of the best-selling autobiography of the high-profile former captain of Australia's men's national team, Johnny Warren, "Sheilas, Wogs and Poofters" (Warren, Harper \& Whittington, 2002) opened a panoply of potential theoretical inquiry. Being pejorative vernacular for "females, immigrants and homosexual men", the subsequent use of gender theory, feminist theory and migrant theory could have provided a more sophisticated lens through which soccer could have been researched. There is no evidence in the literature that this opportunity, or anything similar, was accepted.

More specifically, given the ubiquity and universality of the ethnicity/migrant themes, it is therefore remarkable that migration theory hasn't been used to inform the soccer scholarship. Kurekova (2011) outlines a template for the diversification of inquiry using migration theory. As it stands soccer research treats the "ethnics" as a homogeneous, amorphous mass. Drawing upon migration theory would produce a more nuanced and developed understanding of 
this phenomenon.

The absence of theoretical application to Australian soccer's experience has meant that the central questions pertaining to it have remained unanswered; vis-à-vis how and why a former British colony and anglophile nation, and then as a multi-cultural society, can have marginalised Britain and Europe's most significant and popular football game? That is, if the scholarship had deduced that soccer's problem was one of xenophobia borne of the post 1950 mass immigration, why then did soccer not rise in lock-step with Australia's subsequent evolution to a celebrated multicultural society through the 1980's and 90's? Atheoretical analyses will serve to reproduce dogma whereas applications of theory will develop a virtuous cycle by building the scaffolding of understanding and inquiry. The scholarship has tacitly accepted the premise that soccer has always been "un-Australian", or as Bourdieu may refer as not being 'of the soil' (Laberge \& Kay, 2002). The body of knowledge therefore submissively accepts the incongruity that, somehow, British colonials who played soccer in the nineteenth century were "immigrants" whereas those who played rugby, cricket or Australian rules football were "real" Australians. The scholarship's ethnicity calculus has then linked the post-1950 multiculturalism with British nineteenth century colonialism and deduced that soccer's problem has always been one of foreignness.

None of which it to say that, of itself, the existing research doesn't offer valued contributions. The place of soccer in Australia's history has been routinely undervalued and serially ignored, something to which the likes of Roy Hay and Bill Murray, to name just two, have turned their considered attention. Ian Syson, too, has leveraged the possibilities provided by digitised newspaper archives to reposition soccer deep amidst the early flirtations of the colonial 'football' activities in Australia, where it had been ignored by journalists and historians alike. Therefore, attention to the history of soccer is vital. Australian soccer history has developed importantly under these dedicated and watchful eyes. And as former South African President Nelson Mandela opined (Mandela, 1994), it is the oppressors who determine the weapons of war, and soccer's Australian struggle has been defined by other football hegemons who've used compliant institutions and media acolytes to at least wedge, if not expunge, soccer from Australia's sports history (Syson, 2018a), creating the nostalgia, myth, invented tradition and sporting amnesia referred to by Vamplew (2017). Syson (2018b) also invoked the term "amnesia" regarding Australia's treatment of its soccer history. For this reason, the volume of historical work is both understandable and necessary.

Nevertheless, soccer's scholarship must move beyond the 'who kicked the ball first' and the ethnicity navel-gazing. This is of interest because since soccer became a point of growing academic focus, Rowe and Lawrence (1996) commented that the study the study of Australian sport in general needed "an effective synthesis of historical and sociological approaches to sport under the conditions of postmodernity" because of the "debilitating malaise in sports history and its tendency to be uncritical, de-contextualised and atheoretical" (p.3). Nauright (1999) also targeted the atheoretical nature of the sports studies' coverage and promoted an interdisciplinary approach to the understanding of sport and an integration with post-modernist critique, postulating that:

In Australia, the debates about what should or could constitute 'sports history' have been particularly divisive and have largely been between those who advocate a more inclusive sports studies, of which sports history is a part, and those who see anything sociological or theoretical as a threat. (p.6)

Ingham (1979) foretold of the dialectic between 'facts' vs 'values' and the role for interdisciplinary, theoretical investigations into sports studies by sourcing Weber's sociological method as a means of contextualising sporting phenomena. Other studies in sport moved into multi-theoretical and interdisciplinary analyses. Examples of these are, but not limited to, Caudwell (2007) utilising 'queer theory', Scraton and Flintoff (2002) feminist theory, Connell (2008) which drew upon gender theory and the notable work of Stewart and Smith (2000) regarding Australian sport and post modernism. Laberge and Kay (2002) analysed Bourdieu's work, focussing on his concepts of 'habitus' and 'field' to inform the sociology of sport and physical activity.

Meanwhile, soccer studies in Australia became an echo chamber where ethnicity themes resonated endlessly. A fuller understanding of soccer in modern Australia has not been actualised. This paper applies a theoretical apparatus to the soccer phenomenon and therefore a refreshed approach to the complexities effecting its place in the culture.

\subsection{Soccer's Illegitimacy}

More recently, research has specifically referred to Australian soccer as a function of its 'legitimacy', or otherwise. Syson (2009) determined that soccer's Australian story has been one of illegitimacy, and notwithstanding its long history, its place has always been questioned:

It seems that proponents of the game must constantly justify themselves in watching, playing, 
preferring this supposedly 'new Australian' sport. Since 1880, soccer has sought welcome in Australian societies only to be rebuffed and rejected as a foreign game, a threat, sometimes even a menace to Australian masculinity and life in general. (p. 136).

Syson (2009) distilled soccer's experience as being "an argument about legitimacy" (p. 136). Syson (2015) stated that "Australian soccer is a game on the edge of legitimacy", surmising that:

The game's legitimacy has been questioned by those outside the game since it was first advocated in the 1860's and while its first fleeting steps of organization were taken in the 1870s. Dozens of reasons - including the game's putative foreignness, feebleness, degenerate participants, absence of masculinity, wealth, corruption, colonialism and imperialism - have been used to cast doubt upon soccer's right (or need) to exist on this continent. (p. 71).

Wagg and Crabbe (2009) also invoked the term by noting that soccer "lacked not so much popularity as cultural legitimacy" (p. 60). Nicholson, Sherry and Osborne (2016) stated that soccer needed to de-ethnicise "if it was to become a viable alternative to other football codes and, in a cultural sense, a legitimate Australian sport" (p. 542). The authors also contend that soccer lacked "cultural longevity and legitimacy" when compared with other football codes - Australian Rules, Rugby League and Rugby Union - and this was because of:

Their establishment in colonial times. By contrast, soccer, owing to its global status as the 'World Game', the history of its local development, its relatively recent status as a national football sport and its continued popularity with migrant cohorts, could be seen to be less effective as a cohesive force contributing to a national identity (p. 543)

These claims (Nicholson et al., 2016) are contestable. Most notably that soccer was absent in colonial times, its appeal to the migrants as a limiting factor in a multi-ethnic society, and its 'recent' status as a national football sport soccer's NSL was the first national football competition of any code in Australia (Gorman, 2017). This example of the myth-making involving soccer also invoked the legitimacy construct but offered neither test nor qualification to the assertion.

Soccer's depiction as a ghettoized sport, organized around ethnic identifiers, ran contrary to the assimilationist sentiment of Australia's hegemonic culture. Whichever way its Australian narrative had been woven, clearly soccer had been portrayed has having broken the social contract, which Deegan (2006) suggests is central to legitimacy theory:

The social contract is used to describe the set of expectations a society holds about how an organisation should conduct its operations. Organisations are expected to 'comply' with the terms (expectations) embodied within the social contract. (pp.169-170).

Labelled as illegitimate and having broken the 'social contract' by failing to assimilate with the established sports of the hegemonic culture, soccer was indeed on the margins. The paradox for soccer was that as Australia was embracing multiculturalism in a broad societal and policy sense from the late 1970's, Australian soccer was on the other hand being bludgeoned for its perceived multicultural composition.

Ultimately, in 2004, soccer's flagship competition, the National Soccer League (NSL), was euthanized by the national governing body. According to Carniel (2009), amongst others, soccer then managed to become part of the sporting mainstream in the early years of the twenty-first century, a legitimate part of the sports culture.

Therefore, this research sought to track the path taken by soccer from cultural outsider to legitimate and mainstream. Walford (2013) stipulates that academic research will make greater use of triangulation of different accounts and data sources and that "more fundamentally, the academic researcher will test data against theory, and the whole enterprise will be theoretically informed" (p. 229). This paper breaks new ground by testing the data gathered from interviews of the powerful people who reformed soccer and then draws from Weber's theory of legitimacy to inform the understanding of soccer's new-found legitimate status.

\section{Legitimacy Theory}

The study of organisational legitimacy has been underway since the 1960's, during which time the understanding of organisations themselves has evolved from them as operating in isolation from the surrounding environment to a more integrative re-conceptualisation, where cultural norms - symbols, beliefs and rituals - are all important dynamics in the organisational environment (Suchman, 1995). Legitimacy affects not only how people act toward organisations, but also how they understand them. Thus, "audiences perceive the legitimate organisation not only as 
more worthy, but also as more meaningful, more predictable, and more trustworthy." (Suchman, 1995, p. 575).

The study of legitimacy is about the study of power; of how it is procured, distributed, maintained and lost. What makes a government legitimate or not; what makes a leader legitimate, or not; what makes a social movement legitimate, or not; what makes an idea legitimate, or not. In the case of this research, what makes a sport legitimate, or not. Legitimacy is concerned with the construction of individual beliefs and the resultant social impacts of those commonly held, individual beliefs. Suchman (1995) defined legitimacy as "a generalised perception or assumption that the actions of an entity are desirable, proper, or appropriate within some socially constructed system of norms, beliefs, and definitions" (p. 574). Zelditch (2001) puts it thus, "something is legitimate if it is in accord with the norms, values, beliefs, practices and procedures accepted by a group" (p. 33). This paper investigates how soccer came to be described in such terms when, previously, it wasn't.

The character of legitimacy is multifaceted, and it will "operate differently in different contexts, and how it works may depend on the nature of the problems for which it is the purported solution" (Suchman, 1995 p. 573). Legitimacy is afforded to, and by, people and institutions. It is a major component of civic culture (Badie, 2001). It is not an inherent characteristic, nor is necessarily a permanent state; legitimacy is not static (Ansell, 2001). Deephouse and Carter (2005) viewed legitimacy as social acceptance that results from adherence to regulative, normative or cognitive norms and expectations. As noted, Deegan (2006) declared the notion of the 'social contract' as being central to legitimacy. Badie (2001) outlined that an understanding of the sociology of legitimacy must incorporate the source of legitimacy, its politicisation and its degree of cultural congruence.

Legitimacy is a critical but vexing concept (Ansell 2001). In studying organisational theory, the word legitimacy is often bandied around, but rarely defined (Suchman, 1995). Hurd (2008) agrees that legitimacy is a difficult concept to study and that it is "a phenomenon that is both internal to actors and intersubjective" and "complicated and entangled in many other concepts, such as interests, habits and cultural practises" but "none of these epistemological differences, however, should prevent a discussion of legitimacy; it is central to social life". (p. 8). Ultimately, legitimacy depends on the beliefs held by the audience (Hurd, 2008). Araujo (2012) suggests that "individuals follow a norm convinced they do it freely, whereas in fact their adherence to the norm is an effect of the unconscious subjugation arising from mechanisms of social reproduction." (p. 158). To more pointedly frame legitimacy theory and understand how Australian soccer entered the realm of the 'culturally normative' - the work of renowned German sociologist, Max Weber, was utilised.

\section{Weber's Theory of Legitimacy}

German sociologist, Max Weber influenced the social sciences immensely (Astore, 2016). Writing an updated 'preface' to the seminal contribution of H .H. Gerth and C. Wright Mills and their translation of Weber's work, which has been a central reference point for Weber scholars for approaching seven decades, Bryan Turner stated "writing now from the first decade of a new century, scholarly interest in Weber shows no sign of abatement" (Weber, 2009, p. xii). According to Ansell (2001), Weber "provided social science with its most enduring empirical approach to legitimacy" (p. 8704). Suchman (1995) refers to Weber as foundational, from which researchers have made legitimacy into an anchor point of vastly expanded theoretical apparatus. Zelditch (2001) places Weber as "the single most important theorist on the subject (p. 39) which is "seminal to all modern thought about legitimacy" (p. 43). Even in challenging Weber's conception of legitimacy, Grafstein (1981) acknowledged its proven dominance as the model for empirical investigation of legitimacy.

Max Weber (1864-1920) outlined his "legitimations of domination", or theory of legitimacy, in Politics as a Vocation (Weber, 1948). Weber's life and intellectual purview spanned the dynamic period of Germany's modern history - late nineteenth and early twentieth century - and his analysis scrutinized the transformation of German agrarian communism to modern capitalism (Turner, 1990). This included unification in 1871 and Germany's transformation from feudal system to constitutional monarchy and federalist system, the ascension of Otto von Bismarck to chancellor and his replacement by Kaiser Wilhelm II, through to the revolution of 1918 and the formation of the Weimar Republic. Weber was both commentator and activist in the development of Germany's new constitution (Senigaglia, 2008).

Weber sought to offer understanding of the role of politics in the creation of a state - German unification provided a portal to the concept of 'state' - where "a state is a human community that (successfully) claims the monopoly of the legitimate use of physical force within a given territory" and later, "hence, politics for us means striving to share power or striving to influence the distribution of power, either among states or among groups within a state" (Weber, 
1948, p. 78).

Further, Weber (1948) observed the 'state' as an inter-relationship of:

... men dominating men, a relation supported by means of legitimate (i.e. considered to be legitimate) violence. If the state is to exist, the dominated must obey the authority claimed by the powers that be. When and why do men obey? Upon what inner justifications and upon what external means does this domination rest? (p.78).

Turner wrote, "Weber's conceptual apparatus is actually meaningless once divorced from the political issues which he sought to address in, for example, his political sociology. To take one crucial issue, Weber's views on leadership, bureaucracy and class structure were developed as part of a debate about the future of Germany and the legacy of Bismarck's chancellorship" (Weber, 2009, p. xv). Of the period concerned, Bismarck was Germany's central character and acknowledged by Weber as the state's driving force (Senigaglia, 2014; Eliaeson, 1991; Weber, 1948).

German unification and Bismarck's role therein clearly provided fertile ground for Weber's theorising of domination. In answering that key question, 'when and why do men obey?' Weber explained that there are three justifications, or "legitimations of domination". These are acclaimed as Weber's Theory of Legitimacy. The first of these is the authority of the 'eternal yesterday'. The second is the authority of the 'extraordinary and personal gift of grace (charisma)'. The third legitimator came by virtue of 'legality'.

Of the 'eternal yesterday' or traditional legitimacy, Weber (1948) referred to "the mores sanctified through the unimaginably ancient recognition and habitual orientation to conform; this is 'traditional' domination exercised by the patriarch and the patrimonial prince of yore" (p. 79). Ansell (2001) interpreted Weber's traditional legitimacy as an "established belief in the sanctity of immemorial traditions and the legitimacy of the status of those exercising authority under them" (p. 8705).

To 'charismatic' authority, he observed the "absolutely personal devotion and personal confidence in revelation, heroism, or other qualities of individual leadership .... as exercised by the prophet or - in the field of politics - by the elected war lord, the plebiscatarian ruler, the great demagogue, or the political party leader" (Weber 1948, p. 79). Ansell (2001) described this as the devotion to or impact of a person of exceptional quality or character and the normative patterns that are established or imputed by their presence and leadership.

The third domination, legal/rational legitimacy, comes "by virtue of the belief in the validity of legal statute and functional 'competence' based on rationally created rules. In this case, obedience is expected in discharging statutory obligations. This is domination as exercised by the modern 'servant of the state' and by all those bearers of power who in this respect resemble him" (Weber, 1948, p. 79). Badie (2001) summarised this as people tending to obey the law.

Hence, Weber's three 'pure' types of legitimacy are crystallised into traditional, charismatic and legal/rational and "these conceptions of legitimacy and their inner justifications are of very great significance for the structure of domination." (Weber, 1948, p.79). Weber's model underpins a diverse range of investigation on legitimacy issues, including for example, management (Suchman, 1995), individual social rights (Araujo, 2012), the anthropology of belief (Lindholm, 2012) and the legitimisation of body tattoos (Irwin, 2001). Webb et al. (2009) employs Weberian typology in clarifying the distinction between "what some large groups in a particular society understand to be legal - as specified by laws and regulations - and what they consider to be legitimate - as specified by norms, values and beliefs" (p. 492) -vis-a-vis traditional versus legal/rational legitimacy. Similarly, DeGrandpre (2006) also wedged the gap between cultural (traditional) legitimacy and legal/rational considerations in discussing drug culture; an illicit drug may have a long-held pattern of cultural acceptance and usage (traditional legitimacy), but its illicitness renders it illegitimate (legal/rational).

Legitimacy is a key concept and a central consideration in an organisation's experience. As noted earlier, scholars have pinpointed Australian soccer's problem as being one of legitimacy. Australian soccer operates in a social and political environment. Its success and/or failure does not occur outside of these considerations. The attitudes, beliefs, decisions and relationships of both people and institutions will determine the sport's success, or otherwise. The degree of legitimacy afforded to an organisation (or a sport) will determine its ability to achieve its objectives, depending on what those objectives are (Suchman, 1995). As Merquior (1980) put it "nothing succeeds like success, whether the ruler is traditionalist, charismatic, or legal-rational; its absence therefore threatens legitimacy in all three types of rulership" (p. 402).

To date, studies of Australian soccer have declared that historically it has existed outside of the mainstream and hadn't been accepted as a traditional, Australian sport. Nevertheless, soccer was seen to transform post 2004 to 
where it is now broadly accepted and considered a mainstream and therefore legitimate sport. The notion of 'legitimacy' has been used but, to date, there has been no application of theory to better understand this central concern.

\section{Methodology}

In 2003, and after over a century of existing on the margins of Australian culture, the Federal Government undertook a review into the governance and structure of soccer. The report that was tabled has become known as the Crawford Report (Georgakis \& Molloy, 2016). Scholars and commentators now refer to Australian soccer in the pre and post Crawford eras. Importantly, as Carniel (2009) amongst others have noted, the post-Crawford era has seen soccer considered as a mainstream sport. For this research, soccer's transformation from illegitimate (pre-Crawford) to legitimate (post-Crawford) Australian sporting consideration was analysed.

Data was collected from semi-structured interviews of a purposive sample and was compared against Weber's theory of legitimacy. The sample was comprised of significant individuals who had either worked in the senior administrative and/or elected positions in Australian soccer or with key stakeholder groups including the government, commercial and media/broadcast sectors. The sample $(\mathrm{N}=22)$ included former Prime Minister John Howard, under whose government's imprimatur the governance and structural reform took place in 2004. Also included were Federal politicians with portfolio responsibilities for sport, Chairpersons, CEOs and other senior management of soccer, CEOs of media partners and senior media commentators/analysts. The key aspect of this sample lay in the significant and senior position each had held at some stage either 'inside' or 'outside' soccer. More than occupying an important vantage point from which their observations could be recorded, this sample represented the body of people who effected soccer's legitimisation. Each was positioned to either procure institutional support for the game or were part of an institution whose support had been sought by soccer. The 'soccer' people could speak directly of the size and nature of the task presented to them as they prosecuted soccer's case whilst those 'outside' spoke directly to the reasons why they, and the organisations they represented, had either remained estranged from the game and/or had since opted to support, and legitimise, soccer.

The data was collected utilising recursive questioning around the theme of legitimacy and narrative interviewing style (Elliot, 2005). The semi-structured nature of the interviews allowed for the flexibility required for this diverse sample to ruminate across a range of issues. However, each participant was posited with three key considerations and questions: their personal, perhaps historical, attitude to and experience with soccer; their view on how/why soccer may or may not have been an illegitimate sport, and; if this status had changed, then how and why? The participants' responses were then compared against Weber's legitimacy theory to ascertain which of Weber's three legitimacy types - charismatic, traditional or legal/rational - were identifiable in the data and if so, to what degree.

\section{Results}

The sample uniformly aligned with the pre and post Crawford 'legitimacy' delineation. The spectrum of views included notions that soccer became legitimate 'certainly compared to where it was', through to it now being considered a bona fide part of mainstream Australian sporting culture. The former sentiment was best summed-up by Participant 22, an entrepreneur and former owner of an Australian professional club who said of soccer's post-Crawford legitimacy "it's $50 \%$ of where it needs to be and $90 \%$ above where it was." Accepting this as the baseline, Weber's theory then enabled elucidation as to the nature of soccer's post-Crawford legitimatisation. The data clearly reflected all three legitimacy types present in soccer's transformation.

Firstly, and specifically, the recruitment by the Federal Government of charismatic legitimator Sir Frank Lowy was agreed across the entire sample as mandatory for soccer's transformation. Lowy, one of Australia's most successful and significant business, corporate and community identities also had a demonstrable history with and interest in Australian soccer (Margo, 2001, 2015).

Secondly, the role of the Federal Government in establishing the framework for the restructure and the funding that was tied to this bespoke an unprecedented legal/rational legitimacy afforded to soccer (Participants 3, 4, 11, 12). Thirdly, all of the participants noted the surging growth at grass roots level that had taken place over time, which reflected that soccer's intergenerational links afforded a measure of traditional legitimacy in Australia. This worked in lock-step with other social phenomena such as the mass-media, marketing and penetration of overseas and international soccer, principally the English Premier League (Participants 2, 5, 14, 17), the feminist movement (Participants 2,15) and the multi-ethnic demographic which had assimilated and begun to populate private schools 
(Participants 2, 4, 11, 15, 16, 21) and other institutions that previously were vestibules of a kind of "soccerphobia", as Syson (2018b) referred to it.

Importantly, secondary data analysis supports the idea that Australian soccer had indeed 'crossed the Rubicon' into legitimacy. According to Participant 19, a federal parliamentarian, soccer's pre-Crawford leadership was completely untrustworthy. A 2013 Department of Health governmental report noted the riven politics and parlous financial position of soccer pre-Crawford, stating that "the game was in a state of dysfunction arising from poor governance, political infighting, lack of strategic direction, poor performances on the field and severe financial stress" ("Executive Summary", 2013). The precarious state of soccer's affairs was clear, the Department of Health report further detailing soccer's travails:

By December 2001 Soccer Australia, as it was then known, faced some serious financial problems with debts exceeding $\$ 2.5$ million. The company was under-capitalized, had already sold off significant future commercial property rights (which subsequently failed to produce the financial returns envisaged) ... The National Soccer League was also in financial crisis. An earlier independent report commissioned by the Board of Soccer Australia had questioned a number of management and financial practices within the Company ... Four separate enquiries had been undertaken into the administration and finances of the national body. Many relationships had developed at all levels with the sport, from club through to the national levels, which raised issues of personal interest over the interest of the sport ... at 30 June, 2002, members' equity in Soccer Australia was a negative \$2.6 million. ("Establishment of Football Federation Australia", 2013)

Once legitimised, soccer's experience improved post-Crawford. The National Soccer League (NSL) closed in April 2004 and was replaced by the A-League in August 2005. The NSL's final-season average attendance was 4119 and its Championship game attracted 9630 spectators ("NSL Grand Final, 2004"). The A-League's first season average was 11628 and Grand Final attendance 41689 ("Ultimate A-League Statistics", n.d.). The Department of Health cited that "even the lowest average annual A-League attendance figures (8,811 in 2010-11) are more than twice the old NSL average crowd numbers of 4,119 in its final season. ("National Leagues", 2013). The average attendances in the A-League across its first decade was 12322 ("Ultimate A-League Statistics", n.d.). The report also referred to the A-League's "major broadcast deal", which according to Cockerill (2012) was unprecedented. Furthermore, pre-Crawford, the men's national team had, apart from 1974, repeatedly failed to qualify for the FIFA World Cup Finals. Warren, et al. (2002) chronicled the failed campaigns. Post-Crawford has seen qualification for four consecutive Finals' tournaments, from Germany 2006 through to Russia 2018. In January 2015, Australia won the Asian Football Confederation (AFC) Cup.

Post-Crawford, soccer's governing body improved its financial position from a "negative equity" position to one recording modest surpluses amidst growing revenues "from $\$ 23$ million in 2004-05 to in excess of \$74 million in 2010-11 ("Financial Performance: Historical Performance," 2013). In 2016, the governing body signed a record \$346 million television broadcast deal (Stensholdt, 2016). By 2017, the operating revenue was in excess of \$105 million (FFA Annual Report, "Financial Report", 2017)

Finally, both reflecting and underpinning soccer's rise, the number of participants continued to grow. The Department of Health report outlined that "the number of participants has grown from 1.1 million to 1.7 million between 2001 and 2009" and that "in fact, the biggest challenge for participation is not how to encourage it, but how to meet the demand" ("Executive Summary", 2013). The number of participants again grew to 1.96 million (Lynch, 2013) and by 2015, there were more registered soccer participants than Australian Rules, Rugby League and Rugby Union combined, making it the most-played team sport in Australia (Morgan, 2015a).

Soccer's Chairman, Frank Lowy, declared in 2013 that "soccer is now mainstream" (Hay \& Murray, 2014). Secondary data analysis indicates a dramatic and immediate turnaround since 2004. This also reflects the charismatic authority and 'Bismarckian' impact of Frank Lowy.

In short, synthesizing the interview data through the Weberian portal, and as further supported by the secondary data analysis, soccer in Australia became, post-Crawford, a legitimate Australian sport. This was due to Frank Lowy's appointment (charismatic), the Federal Government intervention (legal/rational) and the growing popularity of the sport in the community (traditional). As will be noted, and as consistent with Weber's theorising, the charismatic, legal/rational and traditional legitimacy types worked symbiotically. 


\section{Discussion}

This paper provides a poignant vindication of the Weberian perspective on the essence and origin of authority, the legitimation of dominance and its application to the world of sport. Where, generally, studies of Australian soccer have been atheoretical, this research has targeted the key variable that determines soccer's place - or any sport for that matter - in the cultural matrix; legitimacy. Who or what determines the sports that are to be accepted, celebrated, supported and patronised is a matter of import for any society where sport occupies a significant place. Australia is one such country.

It is also a country with an idiosyncratically diverse and poly-amorous sporting culture. Unlike the majority of the world, where soccer is unrivalled as the number one sport (Markovits \& Hellerman, 2001), soccer is not preeminent in Australia, a country unique for indulging four different forms of professional football (soccer, Australian rules football, rugby league and rugby union). All of these aspire to domestic dominance and international recognition. These factors, coupled with a population of 23.6 million people, as it was by the time Australian won the men's Asian Cup for soccer in January 2015 (Australian Bureau of Statistics, 2014) ensures that Australia's sports marketplace is hyper-competitive. Even though Weber's deliberations on legitimacy centred around the politics of the newly unified Germany, Turner stipulated that Weber's ideal types "are to be understood as contributions to an (initially) German political problem: clearly this aim does not in principle preclude the usefulness of Weber's conceptual apparatus in other contexts (Weber, 2009, pp xv-xvi). This paper has shown that Australian soccer is one such "other" context in which Weber's conceptual apparatus proves useful.

Weber's legitimacy theory is particularly applicable because of its conception in Germany's transformation to, and through, unification. Soccer's legitimisation story in Australia has also been one of transformation. Senigaglia (2014) outlined that "through the confrontation with Bismarck's personality, Weber also discovered the primary role that a charismatic personality played in making it possible to found and to organize a new state" (p. 93). For the purposes of comparing soccer against Weber's theory, the sport's re-constitution as Football Federation Australia reflects a correlation with the newness of Bismarck's Germany. Weber's focus on Bismarck and his domineering role in the federalised Germany and development of the theoretical charismatic type assists in understanding the role played and influence exerted by Frank Lowy as Chairman of the restructured organisation. Matheson (1987) outlined that Weber's charismatic type referred to a "specific" person on whom legitimacy "rests exclusively on an individual" (p. 208). Lowy was that specific person for soccer. In particular, Participant 3 noted that Lowy "gave the game instant credibility which no one else could have done ... to people outside the game he gave it legitimacy."

Senigaglia (2014) outlined, "Weber noticed that a strong charismatic personality helped to enhance the sentiment of unity especially in a young nation. Charisma could compensate for the reliability which in older nations was granted by tradition, or alternatively by a well-functioning system of law and by an efficiently working administration" (p. 86). This description fits with soccer's status. Firstly, Australian soccer's political discordance was widely acknowledged and Lowy's appointment to the newly created governing body provided 'unity for the young nation', as it were. Furthermore, Participants 3 and 15 spoke of Australian soccer's messianic complex; the sport's historic desire for a person of significance and resource to realise their salvation from obscurity and deliver on the sport's potential. The presence of such an attitude reveals a predisposition for the charismatic type to establish legitimacy.

Soccer also needed 'compensating' for the incumbency and support it traditionally lacked in Australia's political, commercial and educational institutions that were 'granted by tradition' to other sports in Australia. The 'messiah' or charismatic leader, it was believed, could fast-track that process (Participants 3, 9, 16, 22). Also, as Crawford (2003) and Establishment of FFA (2013) noted, Lowy's appointment would, it was expected and/or perceived right across the interview data, 'compensate' for soccer's administrative and financial disarray.

The Federal Government's intervention was pivotal to soccer's legitimisation. This act was a clear reflection of the legal/rational type. The provision of the funding necessary to both secure soccer's solvency as well as Frank Lowy as leader were politically calculated, rational decisions. Whatever its reasons, the impact of the government's decision to provide funding and other support then, "by virtue of the belief in the validity of legal statute and functional 'competence' based on rationally created rules" (Weber, 1948, 79) conferred upon soccer unprecedented, and vitally important, legal/rational legitimacy.

Lowy needed the government, by virtue of its authority, to anoint the processes of the re-structure. Interview participants were clearly of the view that he wouldn't have returned to lead soccer without the politics being cleared for him and funding being provided to capitalise the governing body (Participant 3 and 16). And government officials, both elected (Participants 1, 8, 11 and 19) and professional (Participants 2 and 18) outlined that the government's intervention could not take proper effect without Lowy, or someone of his ilk. As summed up by 
Participant 16, who said of Lowy:

It was his ability to pick up the phone in those days and convince the government by dint of his own authority, legitimacy and track record, to invest in rebuilding the game on the back of his name. So let's be pretty clear about it, I don't think that there was anyone else who had some football pedigree that could make those calls as quickly as he needed to. The game was stuffed. It needed government to come in financially, and the one bloke around the show who could make those calls where it mattered, and get the money moving quickly, not having to put submissions in, arguing your case before a minister or anything, was Frank.

Matheson (1987) stated that Weber accorded most emphasis in his analysis of traditional domination as a basis of legitimacy to the sacredness of tradition, writing that, "a system of domination can be called 'traditional' if legitimacy is claimed for it and believed in on the basis of the sanctity of order and the attendant powers of control as they have been handed down from the past" (p. 35). Further, command and obedience are legitimate if they are aligned with custom. The growing numbers of players and supporters as reported, developed over soccer's long Australian history, all support the notion of traditional connection. Matheson (1987) refers to the importance of personal relationship that exists between power-holder and power-subject in systems of traditional legitimacy. Not only was Lowy of the requisite corporate and government standing, but his reputation and experience in soccer, acknowledged as co-founder of the NSL in 1977 (Margo, 2001; Gorman, 2017) clearly spoke to a personal relationship with the 'power-subject'.

Yet, despite the overwhelming response to the role of Lowy (charismatic) and the place of government in his recruitment (legal/rational), neither would have taken place if the politicians weren't sensitive to soccer's emergence as a significant player in the sports-social-political complex. Notwithstanding the depth of soccer's history in Anglo-Australia, and despite the often-problematic association with ethnic involvement, consecutive generations of migrants have also built significant support of and passion for soccer. These second, third and fourth generation descendants of non-British European migrants were also now populating private schools (Participants 2 and 15). Historically, these schools were tightly aligned with other football games, which had been institutionalised within their networks. Just under half of the sample noted that soccer had been routinely side-lined by this network. As Participant 2 noted of his alma mater "it was too white-bread to absorb the European migrants and soccer was looked down upon by rugby (union) people and the like" but that nowadays there were more soccer than rugby union teams. The surge in soccer's participation and popularity amidst this significant cohort is noteworthy because it occurred against over a century of marginalisation. This is evidenced by the fact that the organising body for sport in Sydney's elite private schools, the Athletic Association of Great Public Schools (AAGPS), ordained rugby union as its football game in 1892 (“AAGPS”, n.d.). Soccer didn't emerge until 1988 (“AAGPS”, n.d.). The legal/rational act of ignoring soccer over that period denied it any ability to develop traditional legitimacy in this influential sector whilst providing rugby union with precisely that sort of life-giving agency.

Close to half of Participants pinpointed the broadcasting of English soccer on Australian television, “in the 70's and 80 's", as the first fertiliser that stimulated this seed bed. Then, the more aggressively marketed English Premier League, through multiple media channels and subscription television, further accelerated the growth. Participant 14, a media executive, spoke of soccer's historical estrangement from the media-sports complex because of pre-existing biases, established relationships and vested interests but that the landscape was changing rapidly.

Apart from television, soccer was benefitting from other contemporaneous movements. Participant 15 referred to the role of feminism and the increasing influence mothers were having on family activities and sport. This was a precursor to the "soccer mum" phenomenon which emerged in the latter decades of the twentieth century. Respondent 2 felt this worked in concert with the "nanny state" that they believed "we were rapidly becoming". The increasing presence of soccer in consumer advertising was highlighted as a harbinger of the changes afoot (Participants 9, 15).

The combined impact of these variables were eye-catching numbers for soccer. Participant 19 - Federal parliamentarian - spoke of the huge volume of letters received from the community seeking action on soccer, declaring it the most profound of its type they'd experienced. Another, also a Parliamentarian, recalled their time; "when I was in (political) office, football (soccer) and netball were the sports which had our attention most." Soccer has become the most played sport for girls, overtaking netball in 2016 (Morgan, 2015b). As mentioned earlier, soccer was already on this trajectory pre-Crawford. The Lowy-era, its improved image and performance, further added to the impetus.

Tellingly when considering traditional legitimacy, Fujak and Frawley (2013) wrote of the difficulties faced by 
Australia's hegemonic football leagues (Australian Football League and National Rugby League) in expanding into non-traditional territories and that success for either will be more a matter of "decades rather than years" (p.109). This serves to highlight the seed-bed that existed for soccer. That is, without the game's "eternal yesterday" developing a culture of and support for the game, soccer's turnaround couldn't have been so dramatic; soccer's base didn't materialise overnight.

Finally, it is important to note that soccer's legitimisation took effect via the combination of all three legitimacy types. Frank Lowy's stewardship (charismatic) would not have been facilitated without the intervention of the Federal Government (legal/rational). Frank Lowy's personal history with the sport (Margo, 2001, 2015; Gorman 2017) implanted him amidst the sport's traditional legitimacy cohort. In fact, as a migrant success story (Margo, 2001, 2015), he epitomised the evolutionary experience of migrant "new" Australian to pillar of the society and in so doing, became a metaphor for soccer's transition into acceptability (Participant 5). The inter-relationship between these three legitimacy types further validates Weber's theory, which noted that rarely do these pure types operate in isolation but are "highly complex variants, transitions, and combinations" of the pure types (Weber, 1948, p.79). This paper not only shows how Weber's legitimacy theory can be applied to sport but also how the theory's validity is enhanced by the analysis of Australian soccer's legitimisation.

\section{Conclusion}

Whilst soccer scholarship in Australia has not been completely theory free, we can, for the most part, clearly acknowledge that it has not kept pace with other disciplines such as education or political science which have been constantly evolving and transforming themselves with new areas of research and theoretical analyses, facilitating a more sophisticated understanding within those areas of interest. Therefore, this paper has provided a road map, and perhaps an opportunity to discuss and analyse a means by which the scholarship can be enhanced, injecting renewed vigour into research of the soccer phenomenon. This paper has achieved two aims. First, it has provided a theoretical framework to describe the history and sociology that impacted soccer's legitimacy in the earlier days of colonization, but particularly from 2003 and until the high-point of Australian soccer, when a united country saw its men's national team with the Asian Cup in 2015; an Australian-born team defeating the very best that Asia could offer. Second, and more importantly, this paper could act as a springboard highlighting the breadth of research possibilities, in line with the interdisciplinary urgings of John Nauright decades ago. As historian Ian Syson pointed out, Australian soccer has always had to explain itself and justify its existence. In this, it is quite unique in the Australian context; one can't immediately recall other major sports having to justify their place, or "Australian-ness". This question lies at the heart of the story of Australian soccer, yet the atheoretical nature of the investigations so far have done little more than to consistently re-heat the binary assumptions pertaining to the impacts of ethnicity, even before 'ethnics' were to become a consideration post 1950. Further, as important as the 'which game was played first' inquiry is, soccer's story is bigger and more complex than that. If we are to understand soccer better, sport better and by extension, Australia better, soccer studies need to saddle-up to further theoretical analyses if it is to ride into a more substantive future.

\section{References}

AAGPS - Athletic Association of Great Public Schools of NSW. (n.d.). History. Retrieved from http://aagps.nsw.edu.au/about/history/ 15 August 2018

Al Ganideh, S. F. (2018). Soccer and integrating Europe's Muslim minorities: the good, and bad and the ugly. Sport in Society, 21(9), 1258-1278. https://doi.org/10.1080/17430437.2017.1388782

Ansell, C. K. (2001). Political legitimacy. International Encyclopedia of the Social \& Behavioral Sciences, 6, 8704-8706. https://doi.org/10.1016/B0-08-043076-7/01167-0

Araujo, K. (2012). The belief in legitimacy: Social experiences and the relationships of individuals to norms. In Mascareno, A. \& Araujo, K. (Eds.), Legitimization in world society (pp.157-175). Ashgate Publishing Limited, Farnham Surrey.

Astore, R. A. (2016). Defining the Legitimacy and Power of the State Through Weber and Foucault. Inquiries Journal/Student Pulse, 8(05).

Australian Bureau of Statistics. (2014). Australian Demographic Statistics, Dec 2014. Australian Bureau of Statistics. Canberra. 
http://www.abs.gov.au/AUSSTATS/abs@.nsf/Lookup/3101.0Main+Features1Dec+2014

Badie, B. (2001). Legitimacy, Sociology of. In N. J. Baltes \& P. B. Smelser (Eds.), International encylopedia of the social and behavioural sciences (pp. 8706-8709). Oxford: Pergamon. https://doi.org/10.1016/B0-08-043076-7/01911-2

Butta, F. (2018). Reimagining Italian-Australian identities through soccer: Critical notes on a history of Italian soccer clubs in Perth. Coolabah, (24\&25), 62-75.

Carniel, J. (2009). Sheilas, wogs and metrosexuals: masculinity, ethnicity and Australian soccer. Soccer \& Society, 10(1), 73-83. https://doi.org/10.1080/14660970802472676

Caudwell, J. (Ed.). (2007). Sport, sexualities and queer/theory. Routledge. https://doi.org/10.4324/9780203020098

Cockerill, M. (2012). Lowy: Football is on the way up. Retrieved 14 August 2010 from https://www.a-league.com.au/news/lowy-footballs-way

Connell, R. (2008). Masculinity construction and sports in boys' education: A framework for thinking about the issue. Sport, Education and Society, 13(2), 131-145. https://doi.org/10.1080/13573320801957053

Crawford, D. (2003). Report of the Independent Soccer Review Committee into the Structure, Governance and Management of Soccer in Australia. Canberra: Australian Sports Commission.

Deegan, C. (2006). Legitimacy Theory, pp. 161-182. In Hoque, Z. (Ed.), Methodological issues in accounting research: theories and methods and issues. London. Spiramus.

Deephouse, D. L., \& Carter, S. M. (2005). An examination of differences between organizational legitimacy and organizational reputation. Journal of management Studies, 42(2), 329-360. https://doi.org/10.1111/j.1467-6486.2005.00499.x

DeGrandpre, R. (2006). The cult of pharmacology: how America became the world's most troubled drug culture. Duke University Press. https://doi.org/10.1215/9780822388197

Eliaeson, S. (1991). Between ratio and charisma-Max Weber's views on plebiscitary leadership democracy. Statsvetenskaplig tidskrift, 94(4).

Elliott, J. (2005). Using narrative in social research: Qualitative and quantitative approaches. Sage Publications. https://doi.org/10.4135/9780857020246

Establishment of Football Federation Australia. (2013). "Building Australia's football community - Review into the sustainability of football". Department of Health. Retrieved from http://www.health.gov.au/internet/main/publishing.nsf/Content/building-australias-football-community-review-i nto-the-sustainability-of-football building-australias-football-community-review-into-the-sustainability-of-foot ball-establishment-ffa. Canberra, Australia

Executive Summary. (2013). "Building Australia's Football community- Review into the sustainability of football". Department of Health. $\quad$ Retrieved from Http://www.health.gov.au/internet/main/publishing.nsf/Content/building-australias-football-community-reviewinto-the-sustainability-of-football building-australias-football-community-review-into-the-sustainability-of-foot ball-execsummary. Canberra, Australia

FFA Annual Report, "Financial Report". (2017) Retrieved 13 august 2018 from https://www.ffa.com.au/sites/ffa/files/2017-11/FFA_2017_Annual_Review_Digital_0.pdf

Financial Performance: Historical Performance. (2013). "Building Australia's Football community- Review into the sustainability of football". Department of Health. Retrieved from http://www.health.gov.au/internet/main/publishing.nsf/Content/building-australias-football-community-review-i nto-the-sustainability-of-football building-australias-football-community-review-into-the-sustainability-of-foot ball-financial-performance-outlook August 15 2018. Canberra, Australia

Fujak, H., \& Frawley, S. (2013). The Barassi line: Quantifying Australia's great sporting divide. Sporting Traditions, 30(2), 93-109.

Galligan, B., \& Roberts, W. (2003, September). Australian multiculturalism: Its rise and demise. In Australasian Political Studies Association Conference, Hobart (Vol. 29).

Georgakis, S., \& Molloy, S. (2016). From old soccer to new football? Expert accounts of transformations on the world game in Australia post-Crawford Report. Soccer \& society, 17(1), 72-89. 
https://doi.org/10.1080/14660970.2014.919270

Gorman, J. (2017). Death and Life of Australian Soccer. St Lucia. Univ. of Queensland Press.

Grafstein, R. (1981). The failure of Weber's conception of legitimacy: its causes and implications. The Journal of Politics, 43(2), 456-472. https://doi.org/10.2307/2130377

Harrison, G. (1979). What's in an ethnic name? Soccer Clubs in Australia. Canberra Anthropology, 2(2), 23-35. https://doi.org/10.1080/03149097909508625

Hay, R. (2006). 'Our wicked foreign game': why has association football (soccer) not become the main code of football in Australia?. Soccer \& Society, 7(2-3), 165-186. https://doi.org/10.1080/14660970600615286

Hay, R. (2011). Ethnicity, structure and globalization: an argument about Association football in Australia. Sport in society: Cultures, Commerce, Media, Politics, 14(6), 833-850. https://doi.org/10.1080/17430437.2011.587299

Hay, R., \& Murray, B. (2014). A history of football in Australia; A game of two halves. Melbourne: Hardie Grant Books.

Hughson, J. (2000). The boys are back in town: Soccer support and the social reproduction of masculinity. Journal of Sport and Social Issues, 24(1), 8-23. https://doi.org/10.1177/0193723500241002

Hurd, I. (2008). After anarchy: legitimacy and power in the United Nations Security Council. New Jersey: Princeton University Press.

Ingham, A. G. (1979). Methodology in the sociology of sport: From symptoms of malaise to Weber for a cure. Quest, 31(2), 187-215. https://doi.org/10.1080/00336297.1979.10519937

Irwin, K. (2001). Legitimating the first tattoo: Moral passage through informal interaction. Symbolic Interaction, 24(1), 49-73. https://doi.org/10.1525/si.2001.24.1.49

James, K., \& Walsh, R. (2018). The expropriation of goodwill and migrant labour in the transition to Australian football's A-League. International Journal of Sport Management and Marketing, 18(5), 430-452. https://doi.org/10.1504/IJSMM.2018.094349

Kampmark, B. (2017). Conflicting traditions: the FIFA World Cup, Australia and football identities. Sport in Society, 20(5-6), 612-626. https://doi.org/10.1080/17430437.2016.1158479

Kampmark, B. (2018). Australian soccer rivalries: diasporas, violence and the Balkan connection. Soccer \& Society, 19(5-6), 875-887. https://doi.org/10.1080/14660970.2017.1399603

Knijnik, J. (2018a). Imagining a multicultural community in an everyday football carnival: Chants, identity and social resistance on Western Sydney terraces. International Review for the Sociology of Sport, 53(4), 471-489. https://doi.org/10.1177/1012690216665356

Knijnik, J. (2018b). Social agency and football fandom: The cultural pedagogies of the Western Sydney ultras. Sport in Society, 21(6), 946-959. https://doi.org/10.1080/17430437.2017.1300394

Kurekova, L. (2011, April). Theories of migration: Conceptual review and empirical testing in the context of the EU East-West flows. In Interdisciplinary Conference on Migration. Economic Change, Social Challenge. April (pp. 6-9).

Laberge, S., \& Kay, J. (2002). Pierre Bourdieu's sociocultural theory and sport practice. Theory, sport and society, 10, 239-266.

Lindholm, C. (2012). "What is Bread?" The anthropology of belief. Ethos, 40(3), 341-357. https://doi.org/10.1111/j.1548-1352.2012.01261.x

Lynch, M. (2013, November 12). Soccer is closing in as Australia's most popular sport. Sydney Morning Herald. Retrieved

from https://www.smh.com.au/sport/soccer/soccer-is-closing-in-as-australias-most-popular-sport-20131111-2xcg0.ht $\mathrm{ml}$

Mandela, N. (1994). A Long Walk to Freedom: The Autobiography of Nelson Mandela. London: Little Brown and Company.

Margo, J. (2001). Frank Lowy: pushing the limits. Sydney: Harper Collins.

Margo, J. (2015). Frank Lowy: a second life. Sydney: Harper Collins. 
Markovits, A., \& Hellerman, S. (2001). Offside: Soccer and American Exceptionalism, New Jersey: Princeton University Press

Matheson, C. (1987). Weber and the Classification of Forms of Legitimacy. British Journal of Sociology, 38(2), 199-215. https://doi.org/10.2307/590532

Merquior, J. G. (1980). Rousseau and Weber: two studies in the theory of legitimacy. Boston; London: Routledge \& Kegan Paul.

Morgan, R. (2015a). Morgan Research, March 19, 2015. 2014: The top 20 sports played by aussies young and old(er). Retrieved from http://www.roymorgan.com/findings/6123-australian-sports-participation-rates-among-children-and-adults-dece mber-2014-201503182151

Morgan, R. (2015b). Roy Morgan Research, November 24, 2015. More girls now playing soccer than netball. Retrieved from http://www.roymorgan.com/findings/6563-more-girls-now-playing-soccer-than-netball-201511240022

Mosely, P. (1987). A social history of soccer in New South Wales 1880-1957. (Unpublished doctoral thesis). University of Sydney, Australia

Mosely, P. (1994). Balkan politics in Australian soccer. ASSH Studies in Sports History, 10, 33-43.

National Leagues. (2013). "Building Australia's Football community-Review into the sustainability of football". Department of Health. Retrieved from http://www.health.gov.au/internet/main/publishing.nsf/Content/building-australias-football-community-review-i nto-the-sustainability-of-football building-australias-football-community-review-into-the-sustainability-of-foot ball-national-leagues. Canberra, Australia

Nauright, J. (1999). The End of Sports History?' From Sports History to Sports Studies. Sporting Traditions, 16(1), 5-14.

Nicholson, M., Sherry, E., \& Osborne, A. (2016). Negotiating national identity through loss: Australian newspaper coverage of the 2010 FIFA World Cup. Soccer \& Society, 17(4), 540-554. https://doi.org/10.1080/14660970.2014.980739

NSL Grand Final (2004). Perth $d$ Parramatta. Retrieved from http://www.austadiums.com/sport/event.php?eventid=2279 July 18, 2018

Rowe, D., \& Lawrence, G. (1996). Beyond national sport: sociology, history and postmodernity. Sporting Traditions, 12, 3-16.

Scraton, S., \& Flintoff, A. (2002). Sport feminism: The contribution of feminist thought to our understandings of gender and sport. Gender and sport: A reader, 30-46. Psychology Press.

Senigaglia, C. (2008). The German parliament after the political union of 1871. Parliaments, Estates \& Representation, 28(1), 137-150. https://doi.org/10.1080/02606755.2008.9522280

Senigaglia, C. (2014). Parliament and nation-building: Max Weber and the German state. Parliaments, Estates and Representation, 34(1), 76-94. https://doi.org/10.1080/02606755.2014.889364

Spaaij, R., \& Broerse, J. (2018). Sport and the Politics of Belonging: The Experiences of Australian and Dutch Somalis. In Places of Privilege (pp. 105-122). Brill Sense.

Stensholt, J. (2016, December 20). Financial Review. Soccer strikes record \$346m TV deal, December 20, 2016

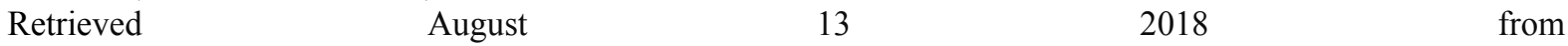
https://www.afr.com/business/sport/soccer-strikes-record-346m-tv-deal-20161220-gteq5r

Stewart, B., \& Smith, A. (2000). Australian sport in a postmodern age. The International Journal of the History of Sport, 17(2-3), 278-304. https://doi.org/10.1080/09523360008714137

Suchman, M. C. (1995). Managing legitimacy: Strategic and institutional approaches. Academy of management review, 20(3), 571-610. https://doi.org/10.5465/amr.1995.9508080331

Syson, I. (2009). Shadow of a game: Locating Soccer in Australian cultural life, Meanjin, 68(4), 136-144.

Syson, I. (2015). Australian soccer on the edge of legitimacy. Leopold Method: intelligent, insightful football analysis. NSW. Pemulwuy 
Syson, I. (2018a). Waiting for Association football: incipient soccer in Australia, 1850-1880. Soccer \& Society, 19(1), 154-167. https://doi.org/10.1080/14660970.2016.1276242

Syson, I. (2018b). The game that never happened. The vanishing history of soccer in Australia. Bannockburn, Victoria. Sports and Editorial Services

Turner, B. S. (1990). Max Weber's Historical Sociology: a bibliographical essay. Journal of Historical Sociology, 3(2), 192-208. https://doi.org/10.1111/j.1467-6443.1990.tb00096.x

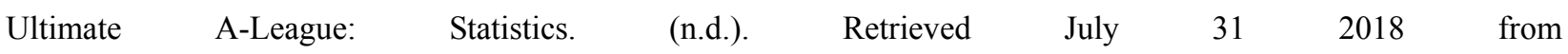
http://www.ultimatealeague.com/records.php?type=pg

Vamplew, W. (1994). Violence in Australian soccer: The ethnic contribution. ASSH Studies in Sports History, 10(1), $1-15$.

Vamplew, W. (2017). Old and Grumpy but Still Game. The International Journal of the History of Sport, 34(5-6), 456-460. https://doi.org/10.1080/09523367.2017.1383387

Wagg, S., \& Crabbe, T. (2009) 'Holding their own': Australian football, British culture and globalization. Soccer \& Society, 10(1), 57-72. https://doi.org/10.1080/14660970802472668

Walford, G. (Ed). (2013). Researching the powerful in education. London: Routledge. https://doi.org/10.4324/9781315072203

Warren, J., Harper, A., \& Whittington, J. (2002). Sheilas, wogs and poofters; an incomplete biography of Johnny Warren and soccer in Australia. Sydney: Random House.

Webb, J. W., Tihanyi, L., Ireland, R. D., \& Sirmon, D. G. (2009). You say illegal, I say legitimate: Entrepreneurship in the informal economy. Academy of Management Review, 34(3), 492-510. https://doi.org/10.5465/amr.2009.40632826

Weber, M. (1948). From Max Weber: Essays in sociology. Trans. and ed. H. H. Gerth and C. Wright Mills. $7^{\text {th }}$ impression 1970, London. Routeledge and Kegan Paul Ltd.

Weber, M. (2009). From Max Weber: essays in sociology. Translated, edited, with an Introduction by H. H. Gerth and C. Wright Mills. With a new preface by Bryan S. Turner. Abingdon, U.K.: Routledge.

Zelditch, M. (2001). Theories of legitimacy. In Jost, J., \& Major, B. (Eds.), The psychology of legitimacy: Emerging perspectives, on ideology, justice and intergroup relations (pp. 33-53). Cambridge: Cambridge University Press. 